\title{
Criminal networks, illegal immigration and the threat to border security
}

\author{
Adrian James \\ Intelligence Manager, Metropolitan Police Service, Middle Market Drugs Project, Serious \\ Crime Directorate, New Scotland Yard, London SW1. Tel: 0870785 7188; \\ Fax: 0870785 7452; email: a.d.james@ise.ac.uk.
}

Received 10 October 2004; Revised and accepted 27 November 2004.

\begin{abstract}
Adrian James joined the Metropolitan Police Service (MPS) in 1977. After eight years seconded to the National Crime Squad, Adrian returned to the MPS in 2001. Until recently he was the Intelligence Manager at Heathrow Airport. He now holds a similar position with the newly formed Middle Market Drugs Project. Adrian holds BSC (Hons) degree in Police Studies and an MSc in Criminal Justice Policy. He is currently conducting research for a PhD in Social Policy at the London School of Economics (LSE). His core research areas are intelligence-led policing and police accountability. Adrian also teaches criminology for the Open University.
\end{abstract}

\section{Abstract}

This paper considers some of the challenges posed to law enforcement agencies in post-modernity by the emergence of transnational criminal networks. Law enforcement, once very much local in character, must now reshape its structures and processes to meet the new and emerging risks presented. Though the paper uses the topic of illegal immigration to reveal something of the nature of such networks and the threat they pose, it also observes that fundamentally, transnational criminal networks are profit-driven and that, perhaps, it is misguided to think of these groups either as commodity-specific or process-specific. The paper concludes that law enforcement agencies need to meet the challenge that such networks present by managing their business with equal flexibility and resourcefulness. Though mechanisms to support that business are being developed, law enforcement agencies must not lose sight of the fact that it is successful outcomes, in the form of the dismantling and disruption of transnational criminal networks, rather than the new processes themselves (that simply underpin law enforcement's efforts) that are important.

\section{INTRODUCTION}

Any discussion of criminal networks and illegal immigration takes place against the backdrop of the wider immigration debate. In the UK, as across much of Europe, immigration is an emotive and heavily politicised subject. Opposing views on whether immigration is a good or a bad thing have become entrenched and despite the current Government's efforts to highlight this country's proud history of welcoming refugees fleeing persecution in their own countries, the reality of the UK's demographic deficit and its need for immigrants to supplement a declining, ageing workforce, many in the country hold to the view that the current level of immigration is bad because ultimately it will bring social unrest and put further strain on what is perceived as an increasingly frail infrastructure.

Whilst recognising that this complex backdrop exists, this paper takes an instrumental approach and focuses its attention
International Journal of Police Science and Management, Vol. 7 No. 4, 2005, pp. 219-229. C Vathek Publishing, 1461-3557 
on illegal immigration which, all too plainly, is a bad thing, not only because it is contrary to law but also because of the human misery and suffering it causes. Illegal immigration strengthens and sustains criminal networks many of which can now claim influence across the globe which is particularly significant in the context of this paper. This paper draws on the author's experiences, so has a particular UK bias, but it is hoped that the core themes explored will be familiar to many engaged in law enforcement both within and beyond these shores.

\section{THE THREE AGES OF MODERN POLICING}

Combating the activities of criminal networks is difficult. Many crimes today present law enforcement agencies with a new set of challenges that often require innovative responses. As Garland (2001) has noted 'the great forces of historical change' including advances in technology, transport and communications have 'transformed the texture of the developed world in the second half of the twentieth century' (p. 78). Nowhere have these changes been more keenly felt than in law enforcement. ${ }^{1}$ Modern policing in the UK began with the establishment of the Metropolitan Police in London in 1829 but for the greater part of the twentieth century, policing was very still very much local in character. Police officers lived in the areas that they were tasked with patrolling. They were responsible for that area and were expected to be a highly visible physical presence; guardian and arbiter often dispensing summary and expressive justice. An extract from Hertfordshire Constabulary's standing orders of 1898 emphasises this localism. Every constable visiting the police station was obliged to visit every prisoner in the cells; knowing the faces of local 'villains' was considered essential for effective policing. ${ }^{2}$ Many remember an age before the mobile telephone, but for much of the twentieth century, officers did not have access to (now considered essential) radio communications. Even when radio equipment became more widely available, doubts about its efficiency meant that the Metropolitan Police continued to publish guidance to officers needing their colleagues' assistance: blow three times on their police whistle or at night, shine their torch in the direction of other police officers. ${ }^{3}$

The second half of the twentieth century (a period now referred to by sociologists such as Garland (2001) as 'late-modernity') was characterised by the rapid advances in technology, transport and communications that were alluded to earlier. It has also featured increasing crime rates and increased opportunities for crime, reduced situational controls and a relaxation of informal controls in society in families and in neighbourhoods. The police responded by adopting a reactive policing style that took police officers away from their communities and put them into patrol cars to provide a rapid response to emergency calls. During this period the police generally waited for things to happen and then responded to events with their new 'scientific' detection techniques. ${ }^{4}$ Relatively basic science epitomised by techniques such as fingerprinting or scene examination for tool marks, hair or fibres or the collation of intelligence reports on card indices or other handwritten records gave way to more sophisticated techniques such as DNA examination and biometrics, computerised databases and crime analysis, but the principles guiding police activity remained the same. The police tended to react to events, fulfilling their "primary mandate of ... emergency order maintenance' (Reiner, 2000 p. 136). This discription is a little simplistic because during this period an embryonic, national, drugs and illegal 
immigration unit emerged in the form of Scotland Yard's Central Drugs Intelligence and Illegal Immigration Unit (CDIIIU), Regional Crime Squads were established and developed and proactive teams of detectives were based around the country with a mandate to prevent and detect serious and organised crime. However, these units represented only a very small fraction of police operational resources.

The third phase from the beginning of the 1980 s up to the present day is characterised by an information-soaked environment. Sociologists such as David Lyon (1999) have suggested that society has moved into the post-modern age while others such as Giddens (cited in Gauntlett, 2002) have argued persuasively that the phenomena that others have characterised as 'post-modern' are usually just the more extreme instances of a fully developed modernity. Whichever school of thought one subscribes to it is clear that the pace of change has quickened. The growth of the Internet has created new crimes (what has come to be known as (cyber-crime') and facilitated the easier and faster commission of many 'old' crimes. There are now more than 50 million mobile telephones in use in the UK and that number grows each day. A large proportion of these are of the pay-asyou-go variety - no self-respecting criminal would be without at least one. Text messaging, almost unheard of twenty years ago is now for many, the preferred form of communication. This mass of communication and electronic data has created a 'datasmog' or an 'information-bog'. During the last two decades, criminal justice authorities have had to reorient their practices in the wake both of these internal and international developments. In the policing sector the result has been bifurcation; increasing emphasis on the importance of more proactive, national structures to combat transnational crime but also an increasing recognition of the importance of service delivery; of meeting local needs by encouraging greater community involvement to enhance problem-solving activities that provide sustainable solutions to policing problems. Though these may perceived to be competing priorities one only need consider the situation of many local communities facing drugs problems or gun crime to begin to see links between organised crime and local policing problems.

\section{THE RISK SOCIETY AND THE RISK ICEBERG}

Ericson and Haggerty (1997) contend that the police have become information brokers to institutions such as insurance companies and health and welfare organisations that operate based on knowledge of risk. In turn, these institutions influence the ways that police officers think and act. These institutions are part of an emerging 'risk society' where knowledge of risk is used to control danger. The current concern with risk is a product of the information-soaked environment, of globalisation and what it brings; a sense of vulnerability in being part of a world system. Globalisation has drawn us out of our self-contained national or local communities into a larger world that offers none of the old protections. Often, risks cannot be delimited spatially and are becoming ever more difficult to manage because of their global nature. In the past, risks were largely perceptible: today the risks are 'global, implicit in postindustrialisation and in the main unseen' (Coker, 2002). This notion of risk may be depicted as an iceberg. Just as only a small portion of an iceberg can be seen above the waterline, so it is often the case that only a small proportion of risks are identified and managed to the satisfaction of decisionmakers; after all one can only plan strategies to address the real (or at least, perceived) 
problems that face an organisation. The greater part of the iceberg consists of risks (or problems) that may have been identified, but are yet to be properly analysed or assessed or, alternatively, as-yet-unidentified risks that are 'off the radar' but nevertheless suggest some vague notion of danger.

Clearly, effective risk management is vital but the 'risk iceberg' analogy suggests that in practice in the information bog of postmodernity, those in law enforcement are usually playing catch-up; rarely sure what is just over the horizon. The US Secretary of Defence, Donald Rumsfeld, has recently provided a very personal view on the risk iceberg model stating,

There are known knowns; there are things we know that we know. There are known unknowns; that is to say there are things that we now know we don't know but there are also unknown unknowns - there are things we do not know we don't know and each year we discover a few more of those unknown unknowns. ${ }^{5}$

Rumsfeld's comments were derided and won him the 2003 'Foot in Mouth' award from the Plain English Campaign for the most nonsensical remark made by a public figure, but to many employed in intelligence work, Rumsfeld's comments do have some resonance: they do seem to describe the murky world within which intelligence officers operate. ${ }^{6}$ Rumsfeld's statement is more than an epistemological conundrum. Intelligence agencies do hold data that are applied by decision-makers to manage risk. Sometimes intelligence gaps are identified and may be addressed but there are often things of which it would probably be to the advantage of those same decision-makers to know that they have no understanding. To explain this further the problem of illegal immigration to the European Union will be considered.

\section{ILLEGAL IMMIGRATION TO THE EUROPEAN UNION}

There has always been illegal immigration. Some individuals have been more enterprising and resourceful than others but in the past such enterprises were essentially small-scale; usually no more than 'cottage industries' but now human smuggling and human trafficking are big business. The routes taken by migrants to enter the EU are both well established and well known. ${ }^{7}$ These include the Baltic route, the Central and Eastern European route, the Balkan route, the Eastern Mediterranean route and the North African route. The enlargement of the EU free movement zone this year brought the EU's borders closer to many would-be migrants. More effective policing (or at least, the promise of more effective policing) in the EU Accession countries has meant that the nexus points have moved eastwards so that they are now situated in Russia, Turkey and the Ukraine, but illegal immigration to the free movement zone has not been significantly reduced. Some migrants may be legally entitled to residence while others obtain leave to remain through marriage, by obtaining work, or as genuine refugees but many others do not meet the criteria to settle legally. Perhaps it is wrong to infer that all migrants are immigrants (ie that they intend to settle in the EU zone) as it is becoming increasingly clear that many individuals periodically return to the countries of their birth, ${ }^{8}$ or are simply transiting through Europe as a means of reaching North America. ${ }^{9}$ What is certain is that the majority of migrants (whether ultimately successful or not in their efforts to remain legally in a Member State or to complete their journey to North America) are usually unable to make their journey to the West without assistance. 
What is (or isn't) illegal immigration probably needs no further explanation here but human smuggling and human trafficking take many forms and are often confused. Human smuggling suggests a level of planning and organisation that is usually the preserve of criminal groups and implicit in that term is that someone else, not the individual being smuggled, is also benefiting financially from that activity. Human trafficking has been defined as including the recruitment, transportation, transfer, harbouring or receipt of persons by means of the threat or use of force or other forms of coercion, fraud or deception ... for the purposes of exploitation (prostitution, sexual exploitation, slavery, forced labour or servitude). ${ }^{10}$

The United Nations Office on Drugs and Crime has suggested that globally each year, 500,000 to 700,000 people are trafficked and that this evil trade earns criminal gangs between $\$ 12$ and $\$ 20$ billion annually (2003). ${ }^{11}$ Evidence seems to show that most facilitation groups work within their own ethnic or family background. Migrants may be charged anything from $£ 2,000$ to $f^{20,000}$ to enter the UK depending on the route travelled and the level of risk of capture or discovery as assessed by the smugglers (who usually carry out their own dynamic risk analyses). ${ }^{12}$ Experience has shown that statistics are notoriously unreliable and it is suggested here that the UNODC figures should be treated with caution. That human trafficking is an income and revenue generator for organised crime groups a priori seems obvious, but the annual trafficking figures provided seem very high. As has been described in the preceding paragraph, the term 'human trafficking' has a particular meaning in this context and in questioning the published figures it is suggested that a proportion of these numbers may relate to human smuggling rather than trafficking. It may be that many cases are defined as trafficking rather than smuggling because those arranging the migrants' passage continue to exercise control over their charges even after they have landed at their destination (either by collecting money from the migrants themselves or from their families in their native countries). ${ }^{13}$ The important issue here is that the smuggling/trafficking question is more than mere semantics. Individuals being trafficked are, very much, victims in their own right and law enforcement agencies must be able to differentiate between the two in order to establish enforcement strategies that meet the victims' needs as well as the needs of the State.

There have been some extremely audacious attempts to enter the UK illegally. For example, in February 2000 nine Afghans, armed with guns and grenades, seised an aircraft on an internal flight from Kabul. The aircraft eventually landed at Stansted Airport near London where the hijackers remained on board with most of their hostages for 70 hours. Eventually they surrendered to police and were subsequently convicted of hijacking. However, in 2003, the Appeal Court ruled that the convictions were unsafe because the law relating to whether the men had acted under duress had been wrongly applied at their trial. Consequently, all of the hijackers were released. Before the aircraft landed in the UK there was doubt about whether or not this really was a hijack and even today the whole question of whether this was a 'real' hijacking or simply a mass immigration has never properly been resolved. The fact is that most of those aboard the aircraft, whether suspected of being involved in the execution or planning of the event or not, remain in the UK today and the confusion over whether or not those on board the plane were victims or criminals, persists.

In another high-profile case, UK Customs officials found sixty Chinese migrants, most already dead but many dying, when they searched a lorry that had arrived at the 
port of Dover on 18 June $2000 .{ }^{14}$ Tragically, the lorry driver had closed the only air vent on the container to avoid detection by immigration officials. Those who died were found to have suffocated. The driver was convicted of 58 counts of manslaughter and jailed for 14 years. Four other men were sentenced to six years' imprisonment in the Netherlands for smuggling illegal immigrants into the UK. Despite this tragedy migrants continue to be smuggled in lorries. However, with the implementation of more effective physical controls (such as the use of $\mathrm{CO}_{2}$ monitors) the greater proportion of individuals now entering the UK illegally use much simpler methods. As Western governments have implemented more effective border controls so there has been a marked increase in the use of stolen or counterfeit travel documents to facilitate illegal migration.

The experience of the police at Heathrow Airport (the world's busiest airport, handling in excess of 60 million passengers annually) is that the majority of illegal immigrants travel to the UK with documents. Counterfeit documents may be tendered to immigration officials with intent to deceive. Genuine (or, sometimes counterfeit) documents that have enabled the migrant to embark on his or her journey are often disposed of prior to immigration controls as a precursor to an application for political asylum. Many migrants arrive in the UK covertly and then obtain a counterfeit passport to facilitate onward travel or assist in gaining employment. Parcels of hundreds of counterfeit passports are regularly seized at UK ports in the possession of couriers or are intercepted in the mail. ${ }^{15}$ Commonly such documents have been counterfeited in Thailand where there is a thriving forgery and counterfeiting industry although there are also a number of other countries in Asia where the manufacture of EU passports is a profitable business. At Heathrow up to 50 individuals a week are intercepted whilst attempting to enter the UK with counterfeit documents. Most of these individuals are facilitated into the UK by criminal networks. Often, a member of the network will accompany the migrant on the flight. The facilitator then relieves the migrant of his or her travel document on arrival in the Member State leaving him or her to apply for political asylum. However, this is not the only method used. In August 2004, the crew of a Boeing 747 aircraft en route to Heathrow from Bangkok discovered six extra passengers. Unknown to the crew, the men had earlier boarded the aircraft for an internal flight but they had remained on board by concealing themselves in a roof panel in the rear of the aircraft. Their travel and concealment had been assisted by a member of a criminal network who was a passenger on the aircraft. Subsequent enquiries showed that in the preceding 10 months the same male had facilitated at least 15 other illegal immigrants using the same method. ${ }^{16}$

\section{ILLEGAL IMMIGRATION AND CRIMINAL NETWORKS}

The smuggling of migrants and human trafficking by criminal networks are two of the fastest growing problems facing EU Member States. Much of the literature on serious and organised crime describes the organisational forms at their heart as 'organised crime groups' but as Williams (2003) has noted: 'most criminal activities are initiated by individuals or small groups and can best be understood as "disorganised crime". This does not mean to suggest that "organised crime' is a chimera. Certainly, crime groups exist, but modern groups do not all conform with the popular media-driven image and in that regard it is probably more accurate to describe them as criminal networks. As Williams (2003a) notes, a criminal 
network is a "highly sophisticated organisational form'. They have the capacity to infiltrate the legal economy, undermine public morals and neutralise law enforcement through corruption at national, regional and even global level. Such groups are often characterised by significant linkages between people, places and events. These networks pose the single greatest challenge to border security. In many countries criminal networks have infiltrated both private and public institutions and as a result have blurred the line between licit and illicit activity. For example, it is broadly accepted that Russian criminal networks are active in many neighbouring countries including, Azerbaijan, Kazakhstan and Georgia and their reach extends into much of Europe and North America. Infiltration of such organisations is always difficult and often impossible. ${ }^{17}$ Prosecutions must be painstakingly assembled and a characteristic of such investigations is that they take a very long time: during the investigation the group is often able to operate successfully and relatively unhindered. ${ }^{18}$

Increasingly, criminal networks operate across a range of markets and in multiple jurisdictions. For example, Chinese criminal networks in Europe are involved in human trafficking but they are also involved in drug trafficking, money laundering and the importation and sale of counterfeit goods (NCIS 2004). Most of the illegal immigration routes described above are also well-established drug-trafficking routes. In that respect it is probably wrong to view the problems that such networks create as 'the immigration problem' or 'the drugs problem' or the 'counterfeit goods problem'. What can be stated is that criminal networks are usually driven by profit motive alone and are generators of crime in the broadest sense. They require sophisticated and well-coordinated organisational responses. Law enforcement agencies must work together to deal effectively with these problems. Police may act as the information brokers' described by Ericson and Haggerty (1997) but crime networks are adept at managing risk. Limiting damage to their criminal enterprises and law enforcement agencies worldwide must play a part if established transnational criminal networks are to be challenged effectively.

Before this paper suggests a response to these problems it may be appropriate to explain what were earlier referred to as the unidentified problems in the context of illegal immigration. In truth it is rather difficult to select an example because, by identifying them, they become identified problems'. The term 'unidentified problems' here may perhaps be misleading but what is implied is that the true nature of the problems in the context of illegal immigration and the threat to border security may not be properly understood. Consider the terrorist threat to the West. It may seem strange to characterise this threat as an unidentified problem, however in the context of illegal immigration there may be some merit in doing so. For example, none of those involved in the 9/11 attack could be considered to be illegal immigrants even though they made false declarations to evade US immigration controls. None of the individuals arrested in the UK in any of the high profile counterterrorism operations in the last two years entered the country illegally — indeed all of the individuals arrested in the latest incidents are British nationals. ${ }^{19}$ This poses the questions: 'Is the terrorist threat to border security the same as that posed to national security?' and 'If these threats are different then what should be the difference in the organisational response?'. It is suggested that these kinds of questions represent the 'unidentified problems' or the 'unknown unknowns' to which Donald Rumsfeld was referring. ${ }^{20}$ 


\section{ORGANISATIONAL RESPONSES AND THE UK NATIONAL INTELLIGENCE MODEL}

Sophisticated organisational responses are required to answer these questions. Most Member States' law enforcement agencies have started to meet the challenge of transnational crime. Many of these responses are being coordinated by the EU. Indeed, the continuing development of the Schengen arrangements, the growth of Europol and increasing cooperation in the areas of justice and home affairs, the EU and its Member States are working hard to improve intelligence-gathering and the coordination of law enforcement activity. In the area of illegal immigration, the EU has established the Risk Analysis Centre (RAC) which is based in Helsinki. The centre's purpose is to conduct threat assessments and risk analyses of illegal immigration and to report on those findings for the benefit of Member States. ${ }^{21}$

The UK's response is the National Intelligence Model (NIM) which was introduced in January 2000 by the National Criminal Intelligence Service. 'The model is the collected wisdom and best practice in intelligence-led policing and law enforcement. It provides the picture that drives effective strategy ...' (NCIS 2000). Within the context of the UK Police Reform agenda the NIM is 'A Model for Policing' to provide strategic direction, to make tactical resourcing decisions about operational policing and to manage risk (Home Office 2004). The key message that the Model seeks to convey is that an accurate identification of current and emerging problems is essential for timely and effective law enforcement interventions. The aim is that problems and risks are identified and resources are targeted in areas that they can be most effective. In other words the NIM represents an attempt to ameliorate problems by doing the best thing on the balance of the available evidence rather than just doing something.

With criminal networks already identified as key drivers of crime at the national and transnational level, the task now is to identify the particular groups to be targeted and to recommend intervention techniques that offer the greatest chance of success. The NIM's key intelligence product is the 'Strategic Assessment'. This document is an evidence-based research package produced by intelligence staff for senior managers. The assessment draws upon a wide variety of sources to produce an accurate picture of the business. In the past, police intelligence units tended to look no further than police databases and indices, but with the advent of the NIM intelligence staff are encouraged to take a much wider view and other sources such as the UK Government, UN and EU studies and reports, academic studies and research programmes and demographic studies are now utilised. Standardised products and techniques mean that intelligence packages are more readily understood and can easily be circulated around the law enforcement community. This process should enable managers to make more effective, evidence-based interventions at local, national and transnational levels.

\section{CONCLUSIONS}

The UK is not alone in facing the challenge of transnational criminal networks and the NIM can only take UK law enforcement so far. The challenge for law enforcement in this country is to look far beyond the borders of the UK and to work even more effectively in partnership with its European partners. The NIM provides a mechanism for the coordination of UK law enforcement activity but as Williams (2003) has noted, to be successful 'governments and law enforcement agencies have to think and act much more in network terms; [and] to 
develop the same kind of flexibility to act both nationally and internationally through the creation of transnational law enforcement networks' based on professionalism, trust and the free flow of intelligence. These improvements can only be effected with the further development of existing national agencies and transnational structures such as Europol and the RAC but equally beneficial would be the development of a 'European Intelligence Model' committed to the development of standardised intelligence products that may more easily be exchanged, understood and acted upon. What is required is a focus on ends rather than means; whichever system is selected, those in law enforcement should not be satisfied until they have discovered a few more of those 'unknown unknowns' and to have secured successful outcomes in the form of the dismantling or at least disrupting of transnational criminal networks. Only then can law enforcement be said truly to be making progress against criminal networks and policing problems.

\section{Notes}

(1) In this regard the paper builds on the idea of the three eras of policing set out by Brian Flood, The Head of Corporate Development of the UK's National Criminal Intelligence Service in his paper 'Are we really serious about intelligence . . . ?' delivered at the National Crime Squad Headquarters, Pimlico, on 14 July 2004.

(2) Standing Orders and Regulations for the Government and Discipline of the Police Force - published 1 January 1898. Retrieved 04/10/2004 from http:// police999.com/hphs/ history/ 150-03.html.

(3) From the, now defunct, Metropolitan Police Instruction Book, at one time mandatory reading for all new recruits to the Service (incidentally, those instructions were still in force in 1977 when this paper's author joined the police service).

(4) Any number of books on the subject may be found: White, P.C. (2003). Crime Scene to Court: Essentials of Forensic Science. London: The Royal Society of Chemistry is a good example.

(5) These comments were made by Rumsfeld at a press briefing in December 2002.

(6) Rumsfeld fought off stiff competition for the award from actor turned California governor Arnold Schwarzenegger whose contribution to the gay marriage debate was 'I think that gay marriage is something that should be between a man and a woman' and the (then) European Commissioner Chris Patten's contention that the British Conservative Party had committed political suicide and was now living to regret it.

(7) Presentation by Tor Burman, Europol Serious Crime Department, Crimes against Persons Unit, Illegal Immigration Group, 14 September 2004, Crime Intelligence and Risk Assessment Conference, Finnish Frontier Guard \& Coast Guard School, Espoo, Finland.

(8) It is not unknown for foreign nationals fleeing persecution in their own countries and provided with UK travel documents that preclude their travel to those countries, to be discovered to be using those documents to return to neighbouring countries and then to cross the land border to their homes.

(9) There have been a number of prosecutions in the UK courts of airlines' document checkers who had facilitated migrants with false documents onto transatlantic flights. Perhaps the most notable investigation was Operation 'Napa Valley' which was conducted in 2000 by the police at 
Heathrow Airport. In 2002, three Air Canada document checkers were convicted of facilitating 78 illegal immigrants to Canada.

(10) Article 3 of the UN Protocol to Prevent, Suppress and Punish Trafficking in Persons.

(11) United Nations Office on Drugs \& Crime 2003.

(12) UK Foreign and Commonwealth Office 2003

(13) This phenomenon was really brought to public consciousness by the plight of the 20 Chinese migrant cockle pickers who were drowned in Morecambe Bay in the north of England in February 2004 whilst attempting to pick said cockles for which they were being paid $£ 10$ per sack.

(14) UK Immigration and Nationality Directorate CHINA Country Information Bulletin 5/2003 - August 2003.

(15) All preceding data in this paragraph were obtained from an interview with a member of the MPS Human Smuggling Team, Heathrow Airport, September 2004.

(16) Based on the author's police experiences.

(17) The author's recent experience of teaching on a CEPOL course attended by border guards from all of the EU Member States suggests that it is more accurate in this context to refer to Russian organised crime groups as 'Russian-speaking organised crime groups' as many originate from countries that were formerly members of the Soviet Union rather than Russia itself.

(18) Based on the author's police experiences.

(19) In August 2004, 12 men were arrested in London, Luton, Hertfordshire and Lancashire on suspicion of a bomb plot. Retrieved 10/10/2004 from http://politics.guardian.co.uk/ homeaffairs/story $/ 0 \% 2 \mathrm{C} 11026 \%$

2C1276444\%2C00.html. In September 2004, four men were arrested in Brent Cross, North London on suspicion of a 'dirty bomb' plot. Retrieved 10/10/2004 from http:// www.guardian.co.uk/uk_news/story/ 0\%2C3604\%2C1313272\%2C00.html

(20) To describe this in another way; a problem or threat may also be unidentified if it is not identified and properly understood by those who have the resources and capability to deal with it.

(21) Threat Assessment - criminal pressure towards the EU external borders; risk analysis - vulnerabilities of society and the EU external border security system itself.

\section{References}

Coker, C. (2002) Security, Independence and Liberty after 9/11 retrieved 04/10/2004 from http://www.21stcenturytrust.org/ post911.htm.

Garland, D. (2001) The Culture of Control. Oxford: Oxford University Press.

Gauntlett, D. (2002), Media, Gender and Identity: An Introduction. London: Routledge. (Extracts available at www.theory.org.uk).

Lyon, D. (1999) Postmodernity (Concepts in the Social Sciences). Buckinghamshire: Open University Press.

NCIS (2000) The National Intelligence Model. London: National Criminal Intelligence Service.

Home Office (2004) The National Policing Plan 2004-2007. London: Home Office.

NCIS (2004) UK Threat Assessment 2003. London: National Criminal Intelligence Service.

Williams, P. (2003) Organised Crime, and Cybercrime: Synergies, Trends and Responses retrieved 04/10/2004 from http:/ /usinfo.state.gov/journals/itgic/0801/ijge/ gj07.htm. 
Williams, P. (2003a) Transnational Criminal Networks retrieved 04/10/2004 from www.rand.org/publications/MR/MR1382/ MR1382.ch3.pdf.
United Nations Office on Drugs and Crime (2003) retrieved 04/10/2004 from http:/ /www.unodc.org/unodc/en/publications/ publications_trafficking.html. 
Copyright of International Journal of Police Science \& Management is the property of Vathek Publishing Ltd and its content may not be copied or emailed to multiple sites or posted to a listserv without the copyright holder's express written permission. However, users may print, download, or email articles for individual use. 